\title{
“GUARDING THE ELECTIONS ONLINE": New Practices, Trust, and Empowerment of Citizens Identities ${ }^{I}$
}

\author{
Antony Lee \\ Kompas Newspaper, Indonesia \\ Email: antony.lee@kompas.id
}

\begin{abstract}
This paper discusses two relatively similar cyber activisms in Indonesia, namely Kawal Pemilu 2014 and Kawal Pilkada 2015 (which mean Guard the 2014 General Election and Guard the 2015 Local Election respectively in Indonesian). Kawal Pemilu that received massive support from the internet users has been acknowledged as a success story of a cyber political crowdsourcing in Indonesia. Kawal Pilkada tried to repeat the success a year after but received fewer supports. Regarding the two organizations, this paper attempts to answer two inter-related questions; (I) What contribution has Kawal Pemilu made to democracy? (2) Why was Kawal Pemilu more popular than Kawal Pilkada? This paper argues that these movements have contributed to democratization in the way that the activisms have reshaped civic culture by introducing new practices, empowering citizens' identities, and promoting trust. Also, the paper explores arguments that political momentum and mainstream media coverage are influential in determining the success of cyber movements. Methodologically, this paper subscribes to qualitative content analysis as a tool to examine interviews materials as well as online and offline texts
\end{abstract}

Keywords: elections, Internet, cyber activism, democracy, civil society, civic culture, Indonesia, crowdsourcing

\begin{abstract}
Abstrak
Makalah ini membahas dua aktivisme dunia maya yang relatif sama di Indonesia, yaitu Kawal Pemilu 2014 dan Kawal Pilkada 2015 (yang berarti Penjaga Pemilihan Umum 2014 dan Penjaga Pilkada 2015 masing-masing dalam Bahasa Indonesia). Kawal Pemilu yang menerima dukungan besar-besaran dari para pengguna internet telah diakui sebagai kisah sukses crowdsourcing politik cyber di Indonesia. Kawal Pilkada mencoba mengulangi keberhasilan itu setahun kemudian tetapi menerima lebih sedikit dukungan. Mengenai kedua organisasi, makalah ini mencoba untuk menjawab dua pertanyaan yang saling terkait; (I) Apa kontribusi Kawal Pemilu terhadap demokrasi? (2) Mengapa Kawal Pemilu lebih populer daripada Kawal Pilkada? Makalah ini berpendapat bahwa gerakan-gerakan ini telah berkontribusi pada demokratisasi dengan cara bahwa aktivisme telah membentuk kembali budaya sipil dengan memperkenalkan praktik-praktik baru, memberdayakan identitas warga, dan mempromosikan kepercayaan. Juga, makalah ini mengeksplorasi argumen bahwa momentum politik dan liputan media arus utama berpengaruh dalam menentukan keberhasilan gerakan siber. Secara metodologis, makalah ini berlangganan analisis konten kualitatif sebagai alat untuk memeriksa bahan wawancara serta teks online dan offline.
\end{abstract}

Kata kunci: pemilihan umum, internet, aktivis siber, demokrasi, masyarakat sipil, budaya sipil, Indonesia, crowdsourcing.

\footnotetext{
I The manuscript was initially presented at the 2016 Sizihwan International Conference on Asia Pacific Studies: "Norms and Institutions in the Asia-Pacific" at National Sun Yat-Sen University, Kaohsiung, Taiwan, November 10-12, 2016. Therefore, the author thanks Dr. Elsa Lafaye de Micheaux, Associate Professor at University of Rennes 2, France, for her input as the discussant of the paper.
} 


\section{INTRODUCTION}

Few hours after the Indonesian presidential election poll closed on July 9, 20I4, in the afternoon, both of the two candidates - Joko Widodo and Prabowo Subianto - declared their victories by citing different quick count poll results. The official announcement was scheduled for July 22 because the vote recapitulations with about I30 million ballots were conducted manually. Joko Widodo claimed his victory by 52 percent against Prabowo's 48 percent; while Prabowo Subianto announced himself as a winner of the election with a gap of less than I percent (thejakartaglobe.com, 2014). The conflicting claims have divided the nation. The narrative of distrust to the ruling government, to the Indonesian General Election Commission, and suspicion among citizens emerged in parallel with the massive media coverage; newspapers, televisions, and online portal in which some of them were also divided in line with the owners' political stance.

Feel concern with the situation, five young Indonesian information technology practitioners who live in five different countries in four continents developed a website "kawalpemilu. org" which means guard the general election in Indonesian. "We did this to prevent the nation from being ripped apart because of two claims of victory that nobody can verify," said Ainun Najib, one of the initiators of the movement, explaining the purpose of the website, as quoted in Financialtimes.com (20I4). The website became widespread through online media, Twitter and Facebook, and was then picked up by mainstream media, which boosted the movement even more. The website had been widely used as a public reference before the election commission announced the result.

In the following year, activists participating in Kawal Pemilu movement tried to repeat the success story in another form. Khairul Anshar, an IT practitioner working in Singapore, along with several activists representing several organizations in Indonesia, introduced Kawal Pilkada, few months before the concurrent local election began. The activists invited reporters from print media, online portals, radio, and $\mathrm{TV}$ outlets to spread the information about their movement through mainstream media. They created more sophisticated features intended not only to provide the recapitulation of the election results but also, among others, to trace candidates' backgrounds. However, unlike Kawal Pemilu, Kawal Pilkada received less attention from the public.

Cyber civic engagements in various socio-political settings have gained plethora of attention from academicians, especially after the Arab Spring revolution in 20II, in which social media were considered a very useful tool for mobilization of people to topple the authoritarian regimes from power (Zaid, 20I6). In Indonesia, discussions on this topic mainly focus on the issues of the use of social media in the election campaign (Priyono et al. 20I4), collective action for influencing policy (Hamid, 20I4), non-political crowdfunding, or mobilizing offline and online political protests (Lim, 2013). This paper is expected to contribute to research in this field by discussing crowdsourcing election monitoring movement happening in the new democratic country.

The emergence of "guard the general election" and "guard the local election" is significant in the way that it has shown a new pattern of political participation in the context of a transitional democratic country like Indonesia. Indonesia has experienced an increase in online participation due to significant improvement in Internet penetration (Gazali, 20I4; Lim, 2013). Immediate questions about those two movements shall revolve around what contribution has it made to democracy? and why did relatively similar movements receive different scales of popular supports? Therefore, this paper will answer two questions: (I) what contribution has Guard the Elections made to democracy? (2) Why did Guard the General Election gain more popular support than did Guard the Local Election?

This paper is structured as follows. The first part discusses internet penetration and online movements in Indonesia. The second part provides background information regarding Kawal Pemilu and Kawal Pilkada movements. The third part presents theoretical discussion. The fourth part will briefly explain the methodology used 
in this paper. The fifth section will discuss how online activisms reshape civic culture, thus contributing to democracy. The sixth part talks about factors that allegedly facilitate the success of online movement. The last part will wrap up the main points of the paper.

\section{INTERNET AND ONLINE MOVE- MENTS IN INDONESIA}

Indonesia has faced a rapid growth in the Internet penetration for the past few years. According to Internet World Stats, in 200o, there were only 2 million Internet users in Indonesia or less than one percent of the Indonesian population. In June 2016, the Internet penetration in Indonesia reached 34 percent with approximately 88 million Internet users (internetworldstats.com, I5/09/20I6). Statista.com predicts there will be 133.5 million Internet users in Indonesia in 2019. In the same year, there will be I05.I million Facebook users and 22.9 million Twitter users. Change.org, an online petition platform, has developed very significant in Indonesia. In 20I2, when it was firstly introduced in Indonesia, only 8,00o people used it. In October 2015, the users reached I.5 million people (Lee, 2016: Ioo).

In demographical term, according to the Association of Indonesian Internet Provider Services (Asosiasi Penyelenggara Jasa Internet Indonesia/APPJI), nearly half of the Internet users in Indonesia are digital native aged I8-25 (49 percent) followed by people aged 26-35 (33.8 percent). In terms of geographical location, DKI Jakarta, the capital city, has the highest Internet penetration ( 56 percent), followed by Yogyakarta (54 percent). When asked what they use the Internet for, most of the respondents of APPJI's survey said that they used it for social media use (See graph I for more details).

Internet has contributed to Indonesian democratization process in many ways. It helped topple the authoritarian President Soeharto in I998. Liu Yangyue (2011: 33) argues that when the Internet first developed in the late I990's, the dictatorial regime in Indonesia "consciously left the Internet space uncontrolled," thus creating "an enclave" of a public sphere. When the authoritarian regime held power, all of the mainstream media in Indonesia were censored. There were stories circulating among senior journalists or media editors that it was common for the government officials to summon the editorial board of media outlets urging particular news not to be published because it might "harm" the state's interests. Of course, during that time, the state was Soeharto himself. In that sense, public discourses were very limited and were strictly controlled.

Graph I. The Uses of Internet in Indonesia ${ }^{2}$

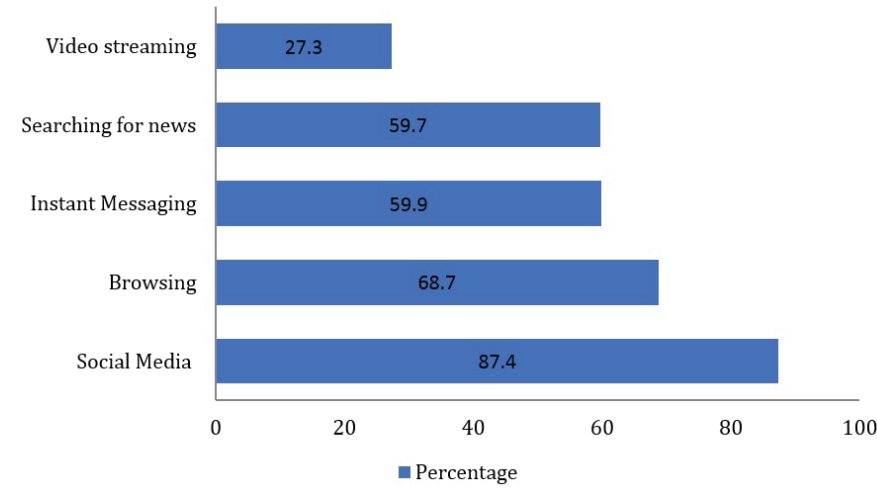

Source: APPJI (2015)

The Internet, however, in its infancy was very helpful to provide alternative discourses about the New Order Regimes. It was through the Internet that articles exposing the corrupt behaviors of the New Order Regime were delivered by academicians or activists living abroad to the hands of Indonesian activists. Once the reform activists in Indonesia received it, the materials were then printed and distributed (Kompas, I9/05/2016).

Nowadays, the contribution of the Internet to Indonesian democracy is far more complex that it was during the late I99os. Gazali (2014: 426) mentions that Indonesia today is arguably an important "live laboratory" for researchers or students who are interested in elaborating the nexus between Internet, or specifically social media, and democratization process. Specific topics related to the link between Internet and social movements has increasingly been the subjects of intensive discussion in mass media as well as academia sphere in Indonesia since the last decade.

$2 \quad$ Based on APPJI survey in 2014, involving 2,000 people in 42 cities in Indonesia. In this survey, the respondents were allowed to provide more than one answer. 
There have been several successful online activisms in Indonesia that are usually brought up as models such as "Coin for Prita" and "Gecko versus Crocodile" (Lim 2013; Priyono et al. 20I4). Coin for Prita was a Facebook movement established to help Prita Mulyasari, a mother of two children, who had to pay the fine of approximately 22,000 USD for a defamation case against the Omni International Hospital in Jakarta. The Hospital sued her because she wrote complaints about inadequate services provided by the hospital, which she subsequently sent to her friends via email. Like a snowball effect, the email was spread widely online. (Lim, 2013). Therefore, she was charged with violating Indonesian Law Number II of 2008 about Electronic Information and Transactions. The crowdsourcing movement collected more or less 80,000 USD. Later on, the court decided she was not guilty.

"Gecko versus Crocodile" movements happened during two different occasions. Gecko symbolizes the Corruption Eradication Commission (KPK), while Crocodile refers to the National Police (Polri). KPK was established in 2004 to fight structural corruption. The institution has become an anti-corruption symbol. Polri was established during the early years of Indonesian independence, but, according to several surveys, is noted as one of the most corrupted institutions in Indonesia (jakartaglobe.id, Iо/03/2017). The first episode of the conflicts between the two institutions happened in 2009 when KPK tapped National Judicial Police Chief Susno Duadji's phone. KPK investigated a corruption case. As retaliation, the National Police announced two KPK commissioners Bibit Samad and Chandra Hamzah as suspects of abuse of power case. During a press conference, Susno Duadji mentioned KPK as "Gecko" trying to fight "Crocodile" (Gazali 20I4). People supported KPK via Facebook, thus conducted offline protests. Social media was used as a mobilization tool. Strong supports to KPK in the form of online and offline activities had forced President Susilo Bambang Yudhoyono to intervene and ask Polri to stop the cases against the two KPK's commissioners.
The second episode of "Gecko versus Crocodile" happened in 2012, when KPK investigated a corruption case involving Inspector General Djoko Susilo, the Chief of the National Police's Traffic Corps. As a response, a team of police officers tried to arrest Novel Baswedan, an investigator of KPK who led Djoko Susilo's corruption investigation. Social media was used to invite activists to come to KPK building. Within an hour, hundreds of KPK supporters gathered in an attempt to prevent the Police from arresting Novel Baswedan. Hashtag of \#SaveKPK and \#Presidenkemana (which means "where is the President") became Twitter trending topics in Indonesia. \#SaveKPK was tweeted 39,997 times (Priyono et al. 2014).

Table I. Five Most Popular Petition's Categories Change.org Indonesia

\begin{tabular}{|c|c|c|c|}
\hline $\begin{array}{l}\text { Top } \\
\text { Cate- } \\
\text { gories }\end{array}$ & 2013 & 2014 & 2015 \\
\hline 1 & $\begin{array}{l}\text { Animals' } \\
\text { welfare } \\
(337,907)\end{array}$ & $\begin{array}{l}\text { Democracy } \\
(239,911)\end{array}$ & $\begin{array}{l}\text { Anti-corruption } \\
(501,561)\end{array}$ \\
\hline 2 & $\begin{array}{l}\text { Environ- } \\
\text { ment } \\
(134,635)\end{array}$ & $\begin{array}{l}\text { Animals } \\
(129,191)\end{array}$ & $\begin{array}{l}\text { Environment and } \\
\text { animal }(325,353)\end{array}$ \\
\hline 3 & $\begin{array}{l}\text { Human } \\
\text { rights } \\
(65,647)\end{array}$ & $\begin{array}{l}\text { Environment } \\
(117,406)\end{array}$ & $\begin{array}{l}\text { Sports } \\
(263,865)\end{array}$ \\
\hline 4 & $\begin{array}{l}\text { Health } \\
(21,060)\end{array}$ & $\begin{array}{l}\text { Child's rights } \\
(115,759)\end{array}$ & $\begin{array}{l}\text { Tolerance } \\
(210,292)\end{array}$ \\
\hline 5 & $\begin{array}{l}\text { Culture } \\
(18,929)\end{array}$ & $\begin{array}{l}\text { Media } \\
(79,000)\end{array}$ & $\begin{array}{l}\text { Criminal Justice } \\
(139,661)\end{array}$ \\
\hline
\end{tabular}

Source: houseofinfographics.com (2013-2015)

There had been many more movements since then. Some succeeded, but many others failed. The movements brought up various issues, but political issues have recently gained more attention from the internet users. Data provided by Change.org data clarify this phenomenon. In 2013, the most signed petitions in Change.org Indonesia were related to animals' welfare, and then in 2014 democratic issue took over. In 20I5, it was anti-corruption petitions that attracted Internet users the most (see Table I).

Usman Hamid, the co-founder of Change. org Indonesia in his book Digital Nation Movement (2014) argues that the significant increase 
in the number of people signing Change.org petitions show that people are eager to use social media as a tool to fulfill public interests. Social media have opened possibilities for the "average" people to start their political movements. However, Hamid also notes that the Internet provides opportunities for the government to spy on critical citizens. Moreover, in Indonesia, the Law of Electronic Information and Transactions can be used to sue critical citizens by accusing them of spreading false information.

\section{ABOUT GUARD THE ELECTIONS}

2014 and 2015 were important years for the Indonesian democracy. In 2014 Indonesia held a legislative election and a presidential election. The presidential election was allegedly one of the most polarized elections in the history of the Indonesian democracy. There were two candidates who fought tooth and nail during the election campaign, thus divided the nation into two opposing positions. In one side were Prabowo Subianto, a retired three-star general, and Hatta Rajasa, a former Coordinating Minister for the Economy, who were supported by six parties consisting of both nationalist and Islamic parties. In the other side were Joko Widodo, the then governor of Jakarta, and Jusuf Kalla, the former Vice President, who were supported by five political parties also consisting of both the nationalist and Islamic parties.

In the presidential election, approximately I90 million voters were registered in 497 districts and municipalities distributed within 478,685 polling stations. The participation rate was 70.9I percent with 133 million valid votes (KPU 20I4). It was during this occasion that Kawal Pemilu or Guard the General Election emerged. Kawal Pemilu had some soft leadership structure with the five founders of the website as an inner circle. In the second layers, there were about 700 volunteers recruited through Facebook, whose main task was to calculate vote results based on $C_{\text {I }}$ form or ballot recapitulation at the level of poll station taken from the election commission's website (ft.com, I8/07/20I4). In the outside of the second layer, there were thousands of independent members of the movement who could scrutinize the data, validate data of $\mathrm{C}_{\mathrm{I}}$ form, recheck the $\mathrm{C}_{\mathrm{I}}$ form with real data in their neighborhood.

The five initiators - who were nicknamed Pandawa Lima (which means five knights in Indonesian), five noted figures in an epic story in Javanese culture - played the role as "choreography of assembly" (Gerbaudo: 2012 in Fuchs, 2012: 783 and in Dahlgren, 2013: 86). Their leadership style was not hierarchical. They provided guidance for the volunteers on what they could do and how they should do it. However, besides that directive work, they could not control all of the independent members who actively checked the data and then spread the ongoing recapitulation through social media such as Twitter, Facebook, or other types of online media. In the end, Kawal Pemilu recapitulated 99.76 percent of the $C_{I}$ forms. They concluded that Prabowo-Hatta received 46.99 percent, while Jokowi-Kalla received 53.0I percent. Their calculation was very close to the official result announced by the election commission a week later; 46.85 percent for Prabowo-Hatta and 53.15 percent for Jokowi-Kalla (KPU 20I4).

In 2015, Indonesia made a historical step in its history of democracy. For the first time, the archipelagic country held a concurrent local election to elect 260 mayors and regents as well as nine governors on the same day, December 9, 2015. It was designed to pave the way for a simultaneous election at the national and local level by 2024. There were 875 pairs of candidates participating in the elections or about 3.25 pairs of candidates per region. The vote turnout was 69 percent out of 96 million registered voters (KPU, 2016). Kawal Pilkada or "guard the local election" was established few months before the election. Khairul Anshar, who participated on Kawal Pemilu, established a website kawalpilkada.id as a platform for political crowdsourcing. Unlike Kawal Pemilu, Kawal Pilkada was supported by several civil society organizations, such as the Association for Elections and Democracy (Perludem), TurunTangan (volunteer's platform), Code4Nation, and Data Science Indonesia. However, their organizational arrangements happened to be almost the same as Kawal Pemilu. 
Some of the volunteers of this movement were once the members of Kawal Pemilu. Several social media influencers also supported this movement and endorsed it through social media. Regarding its features, Kawal Pilkada was much more advanced than Kawal Pemilu. While Kawal Pemilu was only designed to show recapitulation result of the election, Kawal Pilkada offers not only vote recapitulation but also candidate's profile and background. Besides, Kawal Pilkada also provided a direct link from its website to The Election Supervisory Agency (Bawaslu) website in order to facilitate those who want to report election fraud or money politics. Kawalpilkada.id also provided the election's info graphic feature.

Despite being more advanced in terms of program and promotion compared to Kawal Pemilu, Kawal Pilkada received less support from netizen. Kawal Pemilu's Facebook page received 50,00o likes, while its Twitter account @kawalpemiluzoI4 was followed by 4,0I 8 accounts. During the first two weeks of its initial operation, kawalpemilu.org was visited 3 million times (fururegov.asia 26/9/20I4). Kawal Pilkada's Facebook account had only 2.099 likes, while its Twitter account @kawalpilkada was followed by 570 netizens. Kawal Pilkada page, kawalpilkada. id, was only visited 55,250 times (Kompas, 2016).

\section{THEORETICAL FRAMEWORK}

This section discusses a theoretical framework used to explain the interrelation between Internet, online social movement, and democracy. Understanding the connection between those themes is crucial in answering the question of in what way Internet - in the form of cyber activism - contributes to democracy. This part will discuss civic culture framework, and also factors that make online social movement gains popular supports.

How the Internet has altered human life cannot be separated from an understanding on how media have influenced almost every aspect of people's life. At the very least, media can provide space for communication among people. It allows for the exchange of information, values, practices, and provides forums for debates. In that sense, media shape the democratic characters of the society (Dahlgren, 2009). Internet offers more potentials compared to a more traditional mass media such as newspaper or television. While the conventional media's pattern of communication is more likely one-to-many, the Internet provides the possibility of many-to-many communication. It also offers cheaper communication cost. In addition, the decentralization character of Internet can facilitate democratization (Yangyue, 20II).

However, an immediate question regarding those arguments will be: Does the Internet always make positive contributions to democracy? There has been plethora of debates on the nexus between internet and democracy. Soon after the Arab Spring in the late 20Io, positive tones toward the democratic potential of internet flourished within public discourses as well as within academic world. As an example, a well-known sociologist, Manuel Castells published "Network of Outrage and Hope: Social Movements in the Internet Age" in 2012. He analyzes several successful online social movements in several countries, such as Iceland, Spain, Middle East, and a transnational anti-globalization movement. However, the techno-optimistic stance sees social media as "harbinger of social change," therefore focusing only on the bright side of the Internet (Lim, 2013). They usually overemphasize the terms of "Twitter revolution" or "Facebook rebellion" (Fuchs, 2012: 777).

However, there were also some pessimistic stances in understanding the internet contribution to democracy or social movements. The perspective of techno-pessimistic, in contrast, highlights only the "weak ties" aspect of online social movement, or the motivation of people engaging in the movement as not political, but "rather impress one's friends" (Morozov, 20II: I86). In addition, recent research provides "darker" pictures in describing the influence of the internet on democracy. Marc Goodman (2015) and Jamie Bartlett (2015) show how internet is used negatively for crimes, trolling, spreading extremism', and is used as tools for racists far-right movements' mobilization. Goodman also argues that the algorithms of social media have created an "echo chambers" 
because it provides information according to internet users individual characters that are generated from their digital foot-prints. In other words, the internet facilitates its users to get information similar to their ideas or to connect them with other internet users sharing similar views, and it therefore tends to polarize societies. The polarization, Gordon Hull argues, poses a threat to democracy because it harms the societies' shared "imagination" that has become a foundation of nation-states (the conversation.com, 6/II/20I7). Since the 2016 US Presidential Election, there has been a discourse on the impacts of the flood of fake information or fake "news" in social media on the election results.

Taking into account those perspectives, this study refuses to take a deterministic position defended by both stances. Since taking an essentialist understanding is unfruitful for an attempt to illuminate dynamic impacts the internet has brought to democracy. It is important to bear in mind that the internet is a tool that can be used for either good or bad purposes, depending on the people who use it. Swati Bute (20I4), as an example, unpacks the role of social media in the mobilization of people for both riots and revolution by using four cases in India. The tools are the same, but racist and hatred messages could lead to ethnic conflicts that may cost the lives of innocent people, while good governance campaign could lead to the widespread of anti-corruption movements.

The internet or, to be more precise, social media such as Facebook and Twitter allegedly have a potential in "facilitating horizontal communication" where organization or individual can communicate, share information and knowledge, and discuss particular issues, which can generate collective action (Dahlgren, 2013: 40). However, being potential does not mean that individuals will automatically engage in civic activities.

Citizens civic engagement is very important because, to function well, democracy needs some level of individuals' engagements, either in the form of electoral participation or non-electoral participation (Dahlgren, 2009). In this paper, civic participation can be understood as citizen activities that brings positive values to the public life. In other words, any activity that might do potential harm to democracy, such as mobilizing riots, cannot be seen as civic activities.

There are several factors that can either facilitate or hinder people to actively participate in the "space" of horizontal communication. Dahlgren (2009: I04-I05) utilizes such elements as a framework of civic culture, which is "features of the socio-cultural world that serves as preconditions for people actual participation in the public sphere". Dahlgren unpacks civic culture into several components, forming a circuit. Each of the components connects to one another in the way that a part of the circuit can contribute to the other and vice versa. He constructs civic culture from six components, namely: knowledge, values, trust, spaces, practices, and identities (Dahlgren, 2009: I08-I23). The relation pattern between civic culture and individuals as agency is understood to be intertwined. It means that civic culture "can shape citizens; they can serve to empower; citizens, in turn, via their practices, can influence the character of civic culture" (Dahlgren, 2009: I06)

The reason why this narrative uses civic culture in the approach to Kawal Pemilu and Kawal Pilkada is that it is able to give a thorough understanding on the nexus between democracy and media including the internet. That is because the framework of civic culture embraces three traditions in the study of democracy and media; public sphere, political communication, and cultural theory (Dahlgren, 2009). The civic culture circuit shall serve as the guideline for the examination of the empirical materials of this study.

This circuit alone, however, more likely than not, is not enough to explain why a particular social movement is thriving while many others have failed to do so. La Rosa (2014: 43) argues that in order to understand what makes a social media movement successful, four factors should be analyzed, namely (I) conditioning factors; (2) motivational situation or trigger factors; (3) people's perception of situation; (4) particular condition of society at the time of mobilization process. Those are psychological factors. 
In short, the theoretical framework has provided an understanding that civic culture can facilitate or hinder people to engage in civic activities. However, citizens, through their practices can also reshape civic culture components. This understanding is influential to understand Guard the Elections' contribution to democracy. In addition, different levels of supports Kawal Pemilu and Kawal Pilkada received will be analyzed in socio-condition settings during which those movements emerged (La Rosa, 20I4).

\section{METHODOLOGY}

The materials of this paper were collected through semi-structured interviews. This paper also makes use of some of the relevant texts; news coverage as well as online discussion on the movements' Facebook page. A semi-structured interview was chosen due to its advantage in allowing the researcher to take control of research process in order to make sure the research aim is achieved, while still providing enough room for trigger for spontaneous answers from the sources (Cohen et al., 2007). The interviewees were selected through a purposive snowball sampling. The initial source was asked to recommend other potential sources that might have information regarding the research topic. Initial contacts with social, or cultural relations help in keeping the refusal rate low and enable the researchers to cross-check information from one respondent to another (Cornelius, 2003).

The interviewees are political journalists who reported the Indonesian Presidential Election and the concurrent local election, volunteers of Kawal Pemilu and Kawal Pilkada, and the Indonesian election management body commissioners. In total, I interviewed eight people. Cohen at al. (2007) argues that for qualitative inquiry, the number of respondents might be smaller than that of quantitative research. In addition, its number might depend on time, money, and number of researchers. In this sense, I use a theoretical saturation in conducting the interviews. The interviews were conducted in September and October. Each interview took 20 minutes to 45 minutes. The collected materials were then analyzed by using theoretical qualitative content analysis. All of the interview materials were transcribed. After that, the materials were coded openly and then categorized (Bryman 2004). The codes were categorized in accordance with civic culture framework's components.

\section{RESHAPING CIVIC CULTURE}

This paper tries to understand the contribution Guard the General Election and Guard the Local Elections have made to democracy, thus explaining why popular supports for the two movements were different. The theoretical framework has provided an understanding that democracy needs a vibrant civil society; therefore, it requires active citizens' civic participation in the public spaces. However, civic engagement is not something that appears automatically. Through the concept of civic culture, Dahlgren (2009; 2013; 2014) argues that there is a circuit of components that can hinder or facilitate people's civic engagement; trust, knowledge, value, practices or skills, spaces, and identities. In that sense, strengthening civic culture can be fruitful for democracy. In Indonesia, where the constant dispute between anti-reformist elites who want to regain old privileges and civil society activists who try to keep the reform agenda on its track is so salient, a vibrant civic engagement facilitated by robust civic culture will determine Indonesia's democratic consolidation.

In a solid democratic setting, citizen participation is beneficial to prevent democratic deficit caused by the constant decline in electoral participation. However, in a transitional political setting, citizen engagement is much more important. Antlöv et al. (2010) argue that civil society play an essential role in forcing a shift from a totalitarian government to a democratic government, and thus preserving it. Drawing upon Indonesian case, Meitzner (2012) argues that it is the role of civil society that keeps Indonesia on its democratic track. That is because civil society has repeatedly contested the moves of anti-reformist elites to hijack the Indonesian democratic values. The elites have tried many times to take back old privileges they once had. According to Meitzner, civil 
society is acknowledged as "arena of the polity where self-organizing groups, movements, and individuals, relatively autonomous from the state, attempt to articulate values, create associations, and solidarities, and advance their interests" (2012: 217).

The materials of this study suggest that Kawal Pemilu and Kawal Pilkada, more likely than not have reshaped the three components of the civic culture, namely practices, identity, and trust. Of course, it is important to note that the impacts of the movements on civic culture or democratic engagement cannot be seen directly in the short term, but rather should be understood as an accumulation process. In this sense, Yang (2009:36) argues that "changes in citizens' attitudes and behavior are not sufficient for democratization, but at the same time they are essential aspects of any process leading to it." In other words, the movements influence people's point of views on any possible civic engagement they might encounter in the future.

Having said that, while this study does not aim to seek insight on what had facilitated the emergence of those two movements, the materials provide some insight on it, which will also be discussed briefly. In that sense, this section presents four subsections, namely introducing new practices, empowering citizen's identities, strengthening trust, and transparency.

\section{Introducing New Practices}

Kawal Pemilu is not an entirely new online activism in Indonesia. Prior to its emergence, plenty of online activisms had been established, pursuing many different goals. Freelon (2014: I94) categorizes the goals of online activism into symbolic action, agenda setting, framing, personal transformation, attracting followers, organizing collective action, donations, policy agenda setting, policy change, policy enforcement, and policy impact. It is arguable that the vast majority of the previously mentioned goals can be found in Indonesian online movements. Kawal Pemilu can be categorized as a movement with a purpose of organizing collective actions. Kawal Pemilu, more likely than not, was the first movement that became so successful in organiz- ing collective action to monitor and recapitulate election results. Daniel Zuchron, one of the commissioners of The Indonesian Election Supervisory Agency, confirms it. In an excerpt of an interview, Zuchron mentioned, "Kawal Pemilu (Guard the General Election) surprisingly showed that information technology could be used by a crowdsourcing movement to verify, to validate, and to recapitulate votes. That was an inspiring innovation" (Interview with Zuchron, 20I6).

In this case, it is not exaggerating to claim that Kawal Pemilu has established a benchmark that can potentially inspire similar movement in the future. Dahlgren (2009: II5) argues that the practices are embedded in the spaces which function as a communicative space where citizens can talk and discuss, thus facilitating the emergence of collective actions. With this in mind, via the cyberspaces-Facebook page, WhatsApp group, and the website- the volunteers of Kawal Pemilu communicate, interact, and share skills on how to recapitulate the vote results, how to develop or how to organize a crowdsourcing movement online. In that sense, the more online movements emerge, the more it can contribute to the accumulation of practices or skills that in turn can trigger similar movements in the future.

Kawal Pemilu had allegedly inspired the emergence of Kawal Pilkada. People who once participated on Kawal Pemilu established an improved version of the movement. New volunteers were also recruited. While the volunteers Kawal Pemilu only recapitulated the vote results, the volunteers of Kawal Pilkada also provided information on the background of the local election candidates. The aim of the movement also changed. Kawal Pilkada aimed at establishing a longitudinal local election database, which was designed to share election data to the public. The internet users can access the data freely and openly for a variety of purposes, including for research use. In achieving the goal, the movement's programmer thus created a website that can be utilized for several waves of concurrent local elections (Interview with Anshar, 2016). In this sense, Kawal Pilkada 
has also added another practice that can attract more movement to develop.

\section{Empowering Citizen's Identities}

One of the problems in democracy is the decline of political participation. Among many explanations on the causes of the decline, one particular reason that needs to be highlighted is that people, especially the young generation, do not consider their participation in the political process influential in making changes (Freelon 20I4; Dahlgren 2009; Dahlgren 20II; Dahlgren 20I4). When they feel powerless and have no control over the political process, people tend to withdraw from political activities. Consequently, it reduces individuals' understanding on their identity as "empowered citizens" - even to some degrees - their identity as part of a political community.

Kawal Pemilu and Kawal Pilkada's works have empowered their volunteers. That is because becoming part of the movements made the volunteers feel that they can do something meaningful and they were proud of being part of it. The narrative of "empowered" can be found easily on Guard the General Election's Facebook page' discussion. Soepri Jadi, a volunteer of "guard the election," wrote a comment on the Facebook wall of the movement - Kawal Pemilu 20I4 - on July I9, 20I4; "As an Indonesian citizen who lives in a remote area in Central Java, I am proud of this thing (guard the election). At least it helps clarify the data. Moreover, more proudly I could be part of Kawal Pemilu...Salute for Democracy!!!”.

Interview materials also confirmed the abovementioned observation. All of the four activists' narratives - two activists participated in both movement, and two activists participated only in either Kawal Pemilu or Kawal Pilkada provide salient illustrations of people that felt empowered (Interview with Anshar; Ratna; Herry; and lqbal, 20I6). The narratives are revolving around how the volunteers contributed something for the sake of societies and their country or how they guarded people's vote, thus preventing it from being cheated. In addition, some of volunteers argue that they were equal partners of the election management bodies; they could provide feedback, and the feedbacks were heard and thus followed up by the General Election Commission. The last narrative was confirmed by one of the Commissioners of the Indonesian General Election Commission Ferry Kurnia Rizkiyansyah, who said "they communicated with us when they found out some mistakes in the recapitulation process at some particular poll stations. We checked it on the field, and then we fixed it up. The feedbacks from the citizens are always important for us to guarantee that the election results are fair and just" (interview with Ferry, 20I6).

The activists did not directly admit that their involvements within the movements influenced their civic identity. However, the dignity that they felt when they realized that their works had political impacts is closely connected to civic identity. Dahlgren (20II: 23) argues that "a civic identity empowers people to feel that they can participate in democracy; it is a precondition for agency." The sense of becoming part of a political process arguably can influence individual to take part in other kinds of social movements. Several activists who participated in Kawal Pemilu and Kawal Pilkada showed their willingness to involve in other similar movements (Interview with Anshar; Ratna, 20I6). Furthermore, there are also activists who once participated on Kawal Pemilu or Kawal Pilkada said that they had a plan to take part in social movements within the second wave of the concurrent local election in 2017. Herry, for example, said, "Along with some other friends, I will be organizing an offline political literacy program targeting youth voters in the Jakarta's Governor Election in 2017" (Interview with Herry, 20I6).

\section{Strengthening Trust}

Trust - referred to in Dahlgren's previous works as affinity (e.g. Dahlgren, 2003; Dahlgren 2004; Dahlgren and Olsson 2007) - is classified into two types: trust to institution and trust to other members of society (Dahlgren, 2009: II3). Without trust, it will be nearly impossible to initiate cooperation among citizens. Kawal Pemilu and Kawal Pilkada movements have strengthened trust to the state institutions as 
well as trust to the members of society. In fact, it cannot be denied that some level of trust had facilitated the emergence of both movements. Further details of this matter will be elaborated in the next subsection.

Kawal Pemilu and Kawal Pilkada as crowdsourcing movements are closely connected to collaboration and networking. Kawal Pemilu involved collaboration between programmers as well as ordinary netizens who cared about the Indonesian presidential election results. The core volunteers of Kawal Pemilu were 700 people who recapitulated the $C_{I}$ form, while other volunteers scrutinized the recapitulation to guarantee that the movement's work was correct. Kawal Pilkada also used relatively similar system of working, but it opened more collaborative work with civil society organizations concentrating on elections issues, supervisory agency, or Twitter influencers who could endorse the movement in order to gain widespread supports.

Collaborative works mean that the members of the group experience the dynamic of working with other people, thus generating some sense of trust. This is in line with Dahlgren (2009: II4) argument; "trust can be enhanced by growth in positive civil society experiences among citizens." Trust that is built from experiences working with other people can be a foundation for other potential collaborative works. One of the volunteers confesses, "Even after Guard the General Election has completed its mission, we (the volunteers) still communicate with one another. One day Khairul Anshar asked me to participate in Guard the Local Election, and I said yes," (Interview with Ratna, 20I6).

The work of Kawal Pemilu has also strengthened trust to institution, namely the Indonesian General Election Commission. If citizens do not have other sources of information concerning the elections recapitulation process, it is easier to develop and to spread distrust's narratives to challenge the official election results. Drawing upon observation on Indonesian election management before and during the 2009 general election, Mietzner argues that "Indonesia's election management system lacks the precision needed to authoritatively determine outcomes with very low margins" (20I2: 22I). Mietzner (20I2) furthermore claims that the problem can only be solved through reforms, including a better involvement of civil society in monitoring the election.

During the 2014 Indonesian Presidential Election, the narrative of distrust to the election result had emerged even before the Indonesian General Election Commission announced it. Each candidate supporters were suspicious that their rival would interfere with the election commission. The presence of crowdsourcing initiative from below served as a "watchdog" of the General Election Commission. When the movement calculation was almost identical compared to the official election result from the General Election Commission, it helped to reduce the tension in the society. The facts that supporters of both candidates were involved in Kawal Pemilu movement has yielded a positive impact. An activist argued that, "Some people see Ainun (the founder of Kawal Pemilu) as proJokowi, and I am a supporter of Prabowo. Some of my friends know that, and therefore they trust the recapitulation made by Kawal Pemilu. I said if you do not believe the calculation, you could open the $C_{\text {I }}$ scan and recheck it. The presence of Kawal Pemilu made the election commission's result accountable" (Interview with lqbal, 20I6). It is, however, also important to note that the impact might be extremely different if the General Election Commission was not transparent or even if they took side with any of the two candidates.

\section{Procedural Value: Transparency}

Discussing the contribution of the two movements to democracy through civic culture framework is inadequate without examining factors that facilitated the emergence of Kawal Pemilu and Kawal Pilkada. That is because civic culture and people's civic engagement are intertwined. It means that civic culture "can shape citizens; they can serve to empower; citizens, in turn, via their practices, can influence the character of civic culture" (Dahlgren, 2009: I06). Without such values as openness and transparency (Dahlgren, 2009), there would not be any social movement to closely watch the In- 
donesian elections results. It was the respect to transparency that made the Indonesian General Election Commission decided to upload all of the scanned $\mathrm{C}_{\mathrm{I}}$ forms taken from about 470,000 poll stations in Indonesia on their website (kpu. go.id, 20I4). Without this data, it is highly likely that Kawal Pilkada and Kawal Pemilu would not have been existed (Interview with Ferry and Anshar, 20I6).

Transparency alone might not be enough to provide a sufficient facilitating condition to encourage people to participate in the movement. In the case of Kawal Pemilu and Kawal Pilkada, apparently, certain trust to state institution existed, but it was a trust with skepticism. Trust among the volunteers of the movements was facilitated by the facts that the early initiators of the movement had known each other for some time. In addition, the early recruited volunteers were enlisted through friendship ties. The purpose was to guarantee the quality of the recapitulation since it helped to prevent possible wrongdoing from volunteers who might want to sabotage the movement. Trust to the movement goals that made people volunteered could not be separated from the endorsements the movement got from prominent people through mainstream media. The way mainstream media framed their reports about the movement also boosted trust to the movement. More discussion on this will be elaborated in the next section.

Furthermore, other components of civic culture circuit, such as practices, knowledge, and identity can also be found within the narrative of the activists interviewed for this study. All of the four activists interviewed in this study had been involved in some different social movements before they participated in Kawal Pemilu or Kawal Pilkada. In that sense, it is highly possible that they already had sufficient skills and knowledge from the previous social movements they were involved in. The volunteers' previous experiences working with other individuals might also shape their understanding on identity as part of a political society, thus encouraging them to participate in the election monitoring movements.

\section{DIFFERENT POPULAR SUPPORT}

The previous section has provided some insights on democratic contributions the movements have made. However, the circuit of civic culture still does not provide an adequate explanation on why relatively similar movements ended up with a very different scale of popular support. This paper suggests that political momentum and mainstream media support were the factors that made Kawal Pemilu received more popular support than did Kawal Pilkada. Despite the fact that the two variables are discussed separately, both are interrelated. The two arguments emerged from interview materials. That is also in line with La Rosa (2014) arguments which state that there are psychological factors that can influence the success of online movements.

\section{Political Momentum}

Lim's (2013: 636) argues that in order to gain popular support, cyber movements need to take into account "contemporary culture of consumption," namely "light package, headline appetite, and trailer vision." The interview materials of this paper to some extent support this argument with some critical notes. Both movements had an eye-catching name; Kawal Pemilu and Kawal Pilkada. The word "kawal" or "guard" implies an empowering meaning for those who took part in the movement. However, Lim's observation on several successful and unsuccessful online movements in Indonesia somehow does not sufficiently explain why the two social movements that used similar "package" and offered "headline appetite" ended up gaining a very contrast support?

Interviews with the movements' activists and journalists who wrote articles about election suggested that Kawal Pemilu was so successful because it was supported by political momentum, while Kawal Pilkada did not have the same momentum. This is in line with La Rosa's (20I4: 43) argument which states that the success of online social movements cannot be separated from; (I) conditioning factors; (2) motivational situation or trigger factors; (3) people's perception of the situation; and (4) specific condition of society at the time of the mobilization process. While Lim underlines 
the importance of "packages" of the movement, La Rosa highlights the prominence of sociopolitical factors outside the movement itself: the psychological and emotional factors.

There was a difference in the political "atmosphere" during which the two movements emerged. During the establishment of Kawal Pemilu, the political situation was somehow polarized because of conflicting victory claims made by the two presidential candidates. Therefore, people could feel the division. In response to that, Kawal Pemilu offered a simple solution; people should participate in the movement to guard their vote recapitulation, thus preventing the state from becoming torn apart due to different claims that nobody could verify. This narrative was supported by the fact that the Indonesian General Election Commission did not provide national scale real count, thus preventing citizens from monitoring the vote recapitulation process in real time. Instead, the General Election Commission conducted manual recapitulation, with the final result announced nearly two weeks after the election.

In contrast, the political setting during the emergence of Kawal Pilkada was marked by the absence of political polarization. While there were only two contestants in the Presidential Election, the concurrent local elections had more than 800 candidates in 269 regions. In that sense, there was no simple narrative or binary frame that could be used to attract people to participate. Example of this argument can be found on excerpt below;

"It is all about momentum. During the presidential election, there was a strong momentum where the vast majority of citizens focused their attention on the election. So many people's interests were discussed. In contrast, Kawal Pilkada did not have the same momentum. The local elections were not centralized, but instead dispersed" (Interview with Zuchron, 20I6).

To support that arguments, it is also important to note that public discourses revolving around concurrent local election were mainly procedural issues, such as candidacy disputes that happened mainly because of internal leadership conflict within two old political parties, namely Golkar Party and United Development Party (PPP). In other words, during the time when Kawal Pilkada emerged, there were not sufficient triggering factors. In addition, the 2015 concurrent local election was held in only around 50 percent of all of municipalities in Indonesia. As a consequence, not all of the Indonesian citizens felt connected to the election issue. Moreover, the capital city, Jakarta, a province with the highest internet penetration in Indonesia, was not part of the first wave of concurrent local election.

\section{Mainstream Media Coverage}

Arguing that political momentum was an important factor to explain the different popular support gained by Kawal Pilkada and Kawal Pemilu, this paper also needs to take into account the influence of mainstream media coverage. It cannot be denied that mainstream media still play an important role in people's political life. In the context of election, Priyono et al. (2014) argue that the mainstream media's portrayal can influence people's perspective on a certain candidate. The same argument can arguably be used within the context of online social movement. How mainstream media portray a particular online social movement can influence people's perception of the movement. Online movements might receive lower popular support when the narrative they disseminate is contested by arguments delivered by mainstream media (Lim 2013). Khairul Anshar, the initiator of Kawal Pilkada argued that it was the lack of mainstream media report on Kawal Pilkada movement and about the concurrent local election that made Kawal Pilkada receive fewer popular supports compared to Kawal Pemilu (Interview, 2016). An extract of interview material below serves as an illustration of the argument;

"We collaborated with Twitter influencers to introduce Kawal Pilkada. I realized that people's interest in local election issue was low when

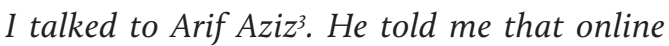
petition in Change.org about clean local election campaign received only few signatories. I believe that mainstream media play an important role in making pilkada (local election) issue somewhat unattractive to the people. It was so different compared to the 2014 presidential election. People's eyes were cast on it". (Interview with Herry, 2016).

3 Arif Azis is Campaign Director for Change.org Indonesia, which is an online petition platform. 
There are some reasons why mainstream media, either television, newspapers, radio or online media, have a substantial influence on people's perception on social movements. According to journalists who write election issue, mainstream media can spread trustworthy information regarding the movements (Interview with Dian, Dianjar, 2016). Even in the era of fast information sharing and the flood of information, mainstream media still have high reputation. That is because of the mainstream media's discipline in maintaining "trustworthiness and accuracy of information" as the important news selection criteria (BelairGagnon, 2015: 79). In that regard, mainstream media coverage can benefit social movements in two ways. First, it can attract citizens' interest to participate with persuasive information about the movement. Secondly, it can function as the movement's source of legitimacy. A positive report about the movement can generate people's trust in the movement.

Why did Kawal Pemilu receive more coverage than Kawal Pilkada? There are two possible answers to this question. First, the relations between mainstream media and the society can work in two ways. On the one hand, media can influence society with their reports. On the other hand, media can also be influenced by society, thus its reports serve as reflection of the society. Dian Ramdhani, a political journalist for Seputar Indonesia Newspaper, mentioned that people's interest in a particular issue can encourage media to report it. In the context of Kawal Pemilu dan Kawal Pilkada, he claimed, people had more interest in the presidential election compared to the concurrent local election. As an impact, mainstream media reported more about Kawal Pemilu compared to Kawal Pilkada (Interview with Dian, 2016). Secondly, Kawal Pemilu received extensive attentions from the media because it was a new kind of political crowdsourcing in Indonesia. That was not the case with Kawal Pilkada. In addition, Kawal Pilkada also had a competitor. The Indonesian General Election Commission also published the recapitulation results on its official website; therefore, people could see the real count quite fast. (Interview with Ferry, 20I6). In that sense, the news "value" of Kawal Pilkada was lower than that of Kawal Pemilu.

\section{CONCLUSION}

This paper discusses the emergence of two online movements on election monitoring in Indonesia. This paper uses civic culture framework, thus taking a middle ground in between the techno-optimistic and techno-pessimistic stances in understanding the role of the Internet in democracy. The paper thus argues that, in order to function well, democracy needs a solid citizens' civic engagement. Kawal Pemilu and Kawal Pilkada have contributed to democracy in the way that it reshaped some components of civic culture, namely trust, identity, and practices. Considering that civic culture framework functions as a circuit, this paper briefly discusses elements of civic culture that facilitate the emergence of the two movements, namely procedural values of transparency. Even though the two movements shared similar roots and a relatively similar way of working; the two movements gained different level of popular supports. Kawal Pemilu received more supports than Kawal Pilkada. It is evident that Kawal Pemilu was supported by political momentum. In addition, Kawal Pemilu received more mainstream media coverage compared to Kawal Pilkada.

Having said that, this article is not intended to disclose the dynamic of Kawal Pemilu and Kawal Pilkada's online and offline activities. This paper only focuses on the online aspect of the movements. More understanding on the online-offline dynamic might reveal more information about the contributions the two movements have made to democracy. Additionally, this paper focuses more on the dynamic outside of the movement to explain different popular supports to Kawal Pemilu and Kawal Pilkada. However, the paper does not explore the movements' organizational logic, whether it was collective action, connective action, or the hybrid between collective and connective action (Bennett and Segerberg, 20I2). More insights into the internal dynamic of the movements might provide more understanding about different popular supports the movements received. 


\section{REFERENCES}

"Ainun Najib, Teknologi Informasi untuk Negeri" [Ainun Najib, Information Technology for a Nation]. (2014), kompas.com, $22^{\text {nd }}$ July. Available in http://tekno.kompas.com/ $\mathrm{read} / 2$ o I4/o7/22/18374667/Ainun.Najib. Teknologi.Informasi.untuk.Negeri (Accessed $2 \mathrm{I}^{\text {st }}$ September 20I4).

"Asia Internet Use, Population Data and Facebook Statistic - June 2016" (2016), Internetworldstats.com, available in http://www. internetworldstats.com/stats3.htm (Accessed $15^{\text {th }}$ September 2016).

"Ci Pemilu 20I4" [CI Form's Election 20I4]. (20I4), kpu.go.id. Available in

"How Open Data Restored Citizen Trust in Indonesian Election”. (20I4), futuregov.asia. Available in http://www.futuregov.asia/articles/20I4/ sep/26/how-open-data-restored-citizentrust-indonesian-el/ (Accessed $26^{\text {th }}$ September 2014).

"Indonesian Technies Crowdsource Election Results”. (20I4), ft.com, I8 ${ }^{\text {th }}$ July. Available in http://www.ft.com/intl/cms/s/o/6c62a8b6oe33-IIe4-85ab-oor44feabdco.html?siteed ition=intl\#axzz3DqpIRJNh (Accessed $20^{\text {th }}$ September 2014).

"Indonesian Police Fifth Most Corrupt Institution in the Country: Transparency International". (20I7). Jakartaglobe.id, IO $^{\text {th }}$ March. Available in https://jakartaglobe.id/context/indonesianpolice-fifth-corrupt-institution-countrytransparency-international (Accessed 8th April 20I7)

"Infografis Change.org Indonesia 20I3". Available in http://houseofinfographics.com/infografis-change-org-indonesia-di-tahun-2013/ (Acccessed $17^{\text {th }}$ September 20I6).

"Infografis Change.org Indonesia 20I4". Available in http://houseofinfographics.com/infografischange-org-20I4/ (Accessed ${ }^{2} 7^{\text {th }}$ September 20I6).

"Infografis Change.org Indonesia 2015”. Available in http://houseofinfographics.com/infografischange-org-20I5/ (Accessed $17^{\text {th }}$ September 20I6).

"Kawal Pilkada dan Tantangan Partisipasi Netizen [Guard the Local Election and the Challenge over Internet Users Participation], (2016), Kompas, $2^{\text {nd }}$ January. Page: 4.

"Media dan Gerakan Kerelawanan [Media and Voluntarism Movements]", (20I6), Kompas, I9 ${ }^{\text {th }}$ May. Page 5.
"Prabowo Refuses to Concede Defeat". (20I4). thejakartaglobe.com, $9^{\text {th }}$ July. Available in http://www.thejakartaglobe.com/news/ prabowo-refuses-concede-defeat/ (Accessed in 2Ith September 2014).

"Profil Pengguna Internet Indonesia 20I4" [the Profile of Indonesian' Internet Users 2014]. (2015). Asosiasi Penyelenggara Jasa Internet Indonesia. Available in https://apjii.or.id/ downfile/file PROFILPENGGUNAINTERNETINDONESIA20I4.pdf (Accessed I $^{\text {th }}$ September 20I6).

"Why Social Media May Not be so Good for Democracy”. (20I7). theconversation.com, 6th November. Available in http://theconversation.com/why-social-media-may-notbe-so-good-for-democracy-86285 (Accessed I6th March 20I8).

Antlöv, Hans., Brinkerhoff, Derick W., Rapp, Elke. (2010). "Civil Society Capacity Building from Democratic Reform: Experience and Lessons from Indonesia”. In Voluntas, Vol. 2I: pp. 4I7-439.

Bartlett, Jamie. (20I5). The Dark Net: Inside the Digital Underworld. Brooklyn: Melville House.

Belair-Gagnon, Valeria. (2015). Social Media at BBC News: The Remaking of Crisis Reporting. Abingdon: Routledge.

Bennett, W.L. and A. Segerberg. (20II). "Digital media and the personalization of collective action: Social technology and the organization of protests against the global economic crisis". In Information, Communication \& Society I4 (6): pp770-799.

Bryman, Alan. 2004. Social Research Methods. ( $\left.2^{\text {nd }} E d\right)$. Oxford: Oxford University Press.

Bute, Swati. (2014). "The Role of Social Media in Mobilizing People for Riots and Revolutions". In Patrut, Bogdan and Patrut, Monica (Eds). Social Media in Politics: Case Studies on the Political Power of Social Media. London: Springer.

Cohen, Louis., Manion, Lawrence., Morrison, Keith. (2007). Research Methods in Education. ( $\left.6^{\text {th }} \mathrm{Ed}\right)$. Abingdon: Routledge.

Cornelius, Wayne A. (2003). "Interviewing Undocumented Immigrants: Methodological Reflection Based on Fieldwork in Mexico and in the US”. In Fielding, Nigel (Ed), Interviewing Volume II. London: SAGE Publication

Dahlgren, Peter. (2003). "Reconfiguring Civic Culture in the New Media Milieu". In Corner, John and Pels, Dick (Eds). Media and the Restyling of Politics. London: SAGE Publications. 
Dahlgren, Peter. (2004). "Civic Cultures and Net Activism: Modest Hopes for the EU Public Sphere". In Conference on One EU-Many Publics?. Scotland, UK, 5-6 February. Available in http://www.sv.uio.no/arena/english/research/projects/cidel/old/WorkshopStirling/ PaperDahlgren.pdf (Accessed $22^{\text {nd }}$ September 20I4).

Dahlgren, Peter. (2009). Media and Political Engagement: Citizens, Communication, and Democracy. Cambridge: Cambridge University Press.

Dahlgren, Peter. (20II). Young Citizens and Political Participation: Online Media and Civic Culture". In Taiwan Journal of Democracy Vol. 7, No. 2: pp. II-25.

Dahlgren, Peter. (2013). The Political Web: Media, Participation and Alternative Democracy. Basingstoke: Palgrave Macmillan.

Dahlgren, Peter. (2014). "Social Media and Political Participation: Discourse and Deflection". In Fuchs, Christian. And Sandoval, Marisol. Critique, Social Media, and the Information Society. Abingdon: Routledge.

Dahlgren, Peter. and Olsson, Tobias. (2007). "From Public Sphere to Civic Culture: Young Citizen's Internet Uses”. In Butsch, Richard (Ed). Media and Public Sphere. Basingstoke: Palgrave Macmillan.

Freelon, Deen. (20I4). "Online Civic Activism: Where Does It Fit?”. In Policy and Internet Vol. 6, No. 2: pp I92-I98.

Fuchs, C. (2012). "Some reflections on Manuel Castells' book Networks of Outrage and Hope: Social Movements in the Internet Age". triple C Io(2): pp775-795. Available at: http:// www.triple-c.at/index.php/tripleC/article/ view/459 (Accessed I ${ }^{\text {st }}$ September 2014).

Gazali, Effendi. (2014). "Learning by Clicking: An Experiment with Social Media Democracy in Indonesia”. In the International Communication Gazette Vol. 76 (4-5): pp 425-439.

Goodman, Marc. (2015). Future Crimes; Inside the Digital Underground and the Battle for Our Connected World. London: Transworld Publishers.

Hamid, Usman (2014). Dinamo: Digital Nation Movement. Jakarta: Bentang Pustaka.

https://pemilu2or4.kpu.go.id/cr.php (Accessed 26 $6^{\text {th }}$ September 2014).

Jadi, Soepri. (20I4). Kawal Pemilu 2014 [Facebook]. I9 ${ }^{\text {th }}$ July. Available in https://m. facebook.com/notes/kawal-pemilu-2oI4/ faqs-frequently-asked-questions-kawalpemiluorg/I45425I508I768II (Accessed 26 $6^{\text {th }}$ September 2014).
Kawal Pemilu 20I4. (20I4). [Facebook]. Available in https://www.facebook.com/pages/KawalPemilu-20I4/I45260I25834I836 (Accessed 2I ${ }^{\text {st }}$ September 2014).

Komisi Pemilihan Umum [The General Election Commission]. (2016). Data and Info graphic Book: 2014 Legislative and Presidential Election. Jakarta: KPU.

La Rosa, Amaro. (2014). "Social Media and Social Movements Around the World". In Patrut, Bogdan and Patrut, Monica (Eds). Social Media in Politics: Case Studies on the Political Power of Social Media. London: Springer.

Lee, Antony. (2016). "Pasang Surut Partisipati Politik di Dunia Maya" [The Tides of Political Engagement on Cyber Spaces]. In Tinjauan Kompas: Menatap Indonesia 2016 [Kompas' Outlook: Indonesia's Outlook 20I6]. Jakarta: Penerbit Buku Kompas

Lim, Merlyna. (2013). "Many Clicks but Little Sticks: Social Media Activism in Indonesia". In Journal of Contemporary Asia Vol. 43, No. 4: pp 636-657.

Mietzner, Marcus. (20I2). "Indonesia's Democratic Stagnation: Anti-Reformist Elites and Resilient Civil Society". In Democratization Vol. I9, No. 2: pp 209-229.

Morozov, Evgeny. (20II). The Dark Side of Internet Freedom. New York: Perseus Book Group.

Priyono, AE et al. (20I4). Media Sosial Alat Gerakan Sipil [Social Media, Civil Movement's Tool]. Jakarta: Public Virtue Institute.

Romero, Leocadia Diaz. (20I4). "On the Web and Contemporary Social Movements”. ”. In Patrut, Bogdan and Patrut, Monica (Eds). Social Media in Politics: Case Studies on the Political Power of Social Media. London: Springer.

Yang, Guobin. (2009). "Online Activism”. In Journal of Democracy Vol. 20, No. 3: pp 33-36.

Yangyue, Liu. (20II). "Crafting a Democratic Enclave on the Cyberspace: Case Studies of Malaysia, Indonesia, and Singapore". In Journal of Current Southeast Asian Affairs Vol. 4: pp. 33-55.

Zaid, Bouziane. (2016). "Internet and Democracy in Morocco: A Force for Change and Instrument for Repression". In Global Media and Communication, Vol. I2, No. I: pp. 49-66. 


\section{Interviews}

Ferry Kurnia Rizkiyansyah, Commissioner of the Indonesian General Election Commission, September 23, 2016.

Daniel Zuchron, Commissioner of the Indonesian Election Supervisory Agency, September 27, 2016.

Khairul Anshar, Initiator of Kawal Pilkada (Guard the Local Elections), September 26, 2016.

Ratna, volunteer of Kawal Pilkada and Kawal Pemilu, September 27, 2016.

Herry Dharmawan, volunteer of Kawal Pilkada, September 23, 2016.

Iqbal Farabi, volunteer of Kawal Pemilu, October 6, 2016.

Dianjar, journalist of TVRI (Indonesian National Broadcasting), September 27, 2016.

Dian Ramdhani, journalist of Seputar Indonesia Newspaper, October 7, 2016. 
